\title{
ZORNIELLA, A REPLACEMENT GENUS NAME FOR ZORNIA SENOWBARI-DARYAN ET DI STEFANO, 2001
}

\author{
Baba Senowbari-Daryan ${ }^{1}$ \& Ioan I. Bucur ${ }^{2 *}$
}

Received: 12 December 2020 / Accepted: 29 December 2020 / Published online: 2 January 2021

In their study of the Middle Triassic calcareous algae of Sicily, Senowbari-Daryan and Di Stefano (2001) erected the new genus Zornia with the type species Zornia obscura based on a "Problematikum" previously illustrated by Zorn (1971, 1972). Recently, we found that the genus name Zornia was preoccupied by a legume of the family Fabaceae (Zornia J.F. Gmelin, 1792; cf. florida.plantatlas.usf.edu/Genus.aspx?id=1321; IRMNG, 2020). According to the Article 54 of the International Code of Botanical Nomenclature (2018), Zornia Senowbari-Daryan et Di Stefano, 2001, is a later homonym of Zornia J.F. Gmelin, 1792, and is illegitimate. Consequently, the new genus name Zorniella SenowbariDaryan et Di Stefano ex Senowbari-Daryan et Bucur, 2021, is proposed to replace Zornia Senowbari-Daryan et Di Stefano, 2001, with the new combination Zorniella obscura Senowbari-Daryan et Di Stefano ex SenowbariDaryan et Bucur, 2021, for its type-species.

\section{ACKNOWLWDGEMENTS}

We thank the reviewers Marc. A. Conrad and Bruno Granier for their remarks and corrections.

\section{REFERENCES}

Senowbari-Daryan, B. \& Di Stefano, P., 2001. Middle Triassic dasycladales in Sicily: Evidence of an Anisian?-Ladinian carbonate platform. Acta Geologica Hungarica, 4 (1): 95-109.

Zorn, H., 1971. Paläontologische, stratigraphische und sedimentologische Untersuchungen des Salvatoredolomits (Mitteltrias) der Tessiner Kalkalpen. Schweizerische Paläontologische Abhandlungen, 91: 1-90.

Zorn, H., 1972. Mikrofazielle Analyse eines mittel triassischen Riffkomplexes in den Tessiner Kalkalpen. Mitteilungen der Gesellschaft der Geologie- und Bergbaustudenten in Österreich, 21: 123-142.

ICBN- Shenzhen Code (2018): https://www.iapttaxon.org/nomen/main.php

IRMNG (2020). Zornia bracteata J.F. Gmel. Accessed at: https://www.irmng.org/aphia.php?p=taxdetails\&id $=10167866$ on $2020-11-29$

\footnotetext{
${ }^{1}$ Geozentrum Nordbayern, Paläoumwelt, Loewenichstraße 28, 91054 Erlangen, Germany, baba.senowbari-daryan@ fau.de

${ }^{2}$ Babeş-Bolyai University, Department of Geology and Center for Integrated Geological Studies, M. Kogălniceanu, 1,

400084 Cluj-Napoca, Romania, ioan.bucur@ubbcluj.ro

* Corresponding author
} 